Article

\title{
China's Land Resources Dilemma: Problems, Outcomes, and Options for Sustainable Land Restoration
}

\author{
Lulu Zhang * (1) and Kai Schwärzel \\ United Nations University Institute for Integrated Management of Material Fluxes and of \\ Resources (UNU-FLORES), 01067 Dresden, Saxony, Germany; schwaerzel@unu.edu \\ * Correspondence: lzhang@unu.edu; Tel.: +49-351-7999-3806
}

Received: 27 October 2017; Accepted: 16 December 2017; Published: 18 December 2017

\begin{abstract}
Pressing issues such as water and food security, health, peace, and poverty are deeply linked to land degradation. We use China's major land restoration programs as a case offering perspective on the existing problems in China's major policies for improving degraded land and maintaining land resources in three dimensions. The shortcomings and outcomes in terms of biophysical consequences, socioeconomic benefits, and political goals are addressed, namely (i) non-integrated land resources management creates new problems while solving existing problems, (ii) non-participatory processes and "one-size-fits-all" measures compromise socioeconomic benefits, and (iii) implementation outcomes conflict with policy targets for sustainable land management and development. Based on discussions for more sustainable land management, we conclude that China needs to create a new mode of 'economy and environment' in plans and actions of restoring degraded land resources. Establishing multifunctional land-use systems based on formulating and balancing multiple benefits/services across socio-ecological sectors can be an option to achieve such a mode. At the end, recommendations are given for research and implementation that are not only vital for China but also relevant for other regions since the challenges of afforestation and sustainable land development faced in China are not unique.
\end{abstract}

Keywords: land degradation; sustainable land management; afforestation; multifunctional land use; ecosystem functions and services

\section{Introduction}

The world is facing development challenges, among which the United Nations (UN) specifies global warming and food and water security as the biggest ones as they are profoundly connected to other global issues such as health, peace, and economic growth. However, land degradation, (e.g., land desertification and soil erosion) deteriorates soil and water quality, limiting land capacity to mitigate global warming and produce sufficient food and clean water for increased population demands. Measures and integrated frameworks have been adopted to reverse land degradation and improve water security [1]. Due to continued changes of drivers and pressures, currently applied measures are no longer sufficient to cope with the challenges. This calls for innovation and transformation of approaches to combat land degradation. Currently, a policy debate is going on to discuss how to move forward; one camp of this debate proposes moving from a sector-oriented to a cross-sectoral approach [2,3]. One of the main arguments is that failures to recognise the inter-connection between sectors have led to land degradation [4]. Similar recognitions stimulate discussions on China's experiences, lessons, and pressing challenges in reversing land degradation in scientific communities [5-7]. 
China's rapid rise is at the expense of land resource sustainability, including soil, water, and plants. According to the latest State of Environment Report [8], China's overall environmental quality has continuously worsened: three-fifths of groundwater and one-fifth of farmland are polluted. The status quo of water and soil deterioration is far from optimistic and gives rise to deep concerns about Chinese health and well-being being threatened by shrinking and degrading land resources. These issues undermine China's ability to achieve the Sustainable Development Goals (SDGs) [9], making it more difficult to adopt the sustainable development concept.

China has long recognised the importance of land sustainability and carried out a number of restoration programmes to control and reverse land degradation, such as the Three North Shelterbelt Project (TNSP) —China's Great Green Wall and Grain for Green Program (GFGP)—-the world's largest reforestation programme (Table 1). These efforts are successful in reducing soil erosion [10], improving soil organic carbon [11], and developing local economy to a certain extent; however, the expected synergy of ecological and economic development has not been achieved due to some problems that occurred during their implementation. For example, recent studies showed that afforestation results in a water opportunity cost of $1100 \mathrm{RMB} /$ ha in contrast to natural vegetation [12] and the costs for afforestation are highly likely to exceed the expected benefits in dryland China [13]. Moreover, improper land management-induced water and soil degradation have become more and more difficult and expensive to recover with increased frequency and severity [14]. Therefore, more efficient approaches are needed to balance water and soil resources management.

So far, many debates about problems and outcomes of China's actions against land degradation focus on a single dimension, either emphasising biophysical processes $[10,15]$ or socioeconomic benefits [12,16], rarely with respect to full dimensions (e.g., biophysical, socioeconomic, and political) as a whole picture. Given this situation, in the following we take a first step to build a foundation for discussion on overall knowledge gaps and the possible way forward. The aims of our work are to (i) highlight shortcomings and present outcomes of the nationwide land restoration in China (i.e., TNSP and GFGP) in three dimensions, (ii) suggest a new approach for land restoration and requirements in decision-making to harmonise ecological and social development, and (iii) give recommendations for research and local implementation using the Loess Plateau in China as an example. With this work, we wish to stimulate dialogues on key issues of land restoration to harmonise sustainable land resources and social development. As a country dealing with some of the most severe land degradation issues in the world, China's experience and lessons are noteworthy and have significant relevance and implications for other countries and regions, particularly where afforestation is considered as a measure to restore degraded land resources.

\section{Materials and Methods}

This work focuses on the dryland part of China, which is vulnerable to changes in land cover (in contrast to more humid areas) and has severe environmental problems, such as land degradation and water shortage. The Loess Plateau (LP) is one such area in China. The LP has a vast expanse of $640,000 \mathrm{~km}^{2}$ and is covered by loess soil that is over $60 \%$ silt and, thus, highly erodible (Figure 1). The precipitation in the LP is unevenly distributed over time and space. The average annual precipitation ranges from 200 to $600 \mathrm{~mm}$ from the northwest to the southeast. In the range of $50-70 \%$ of the annual precipitation falls in July, August, and September and commonly in the form of rainstorms [17]. The natural vegetation of the LP has been destroyed for a long time. Due to improper land use and management over a long period, the land suffers gradual degradation and severe soil erosion. It was estimated that $90 \%$ of the sediment load in the Yellow River originated from the LP [18]. Agriculture is the main land use in this region and the rural livelihoods significantly rely on the ecosystem health. The economic development of the LP is below the national average and far behind the eastern region of China. In particular, the per capita GDP in Gansu province is only 30\% that of the eastern region [19]. To remedy this situation, ecological restoration has been carried out to improve environmental and economic development. The TNSP and GFGP are implemented to a large 
extent on the LP (Figure 1). A short summary of the TNSP and GFGP with regard to goals, measures, and anticipated benefits is presented in Table 1 .

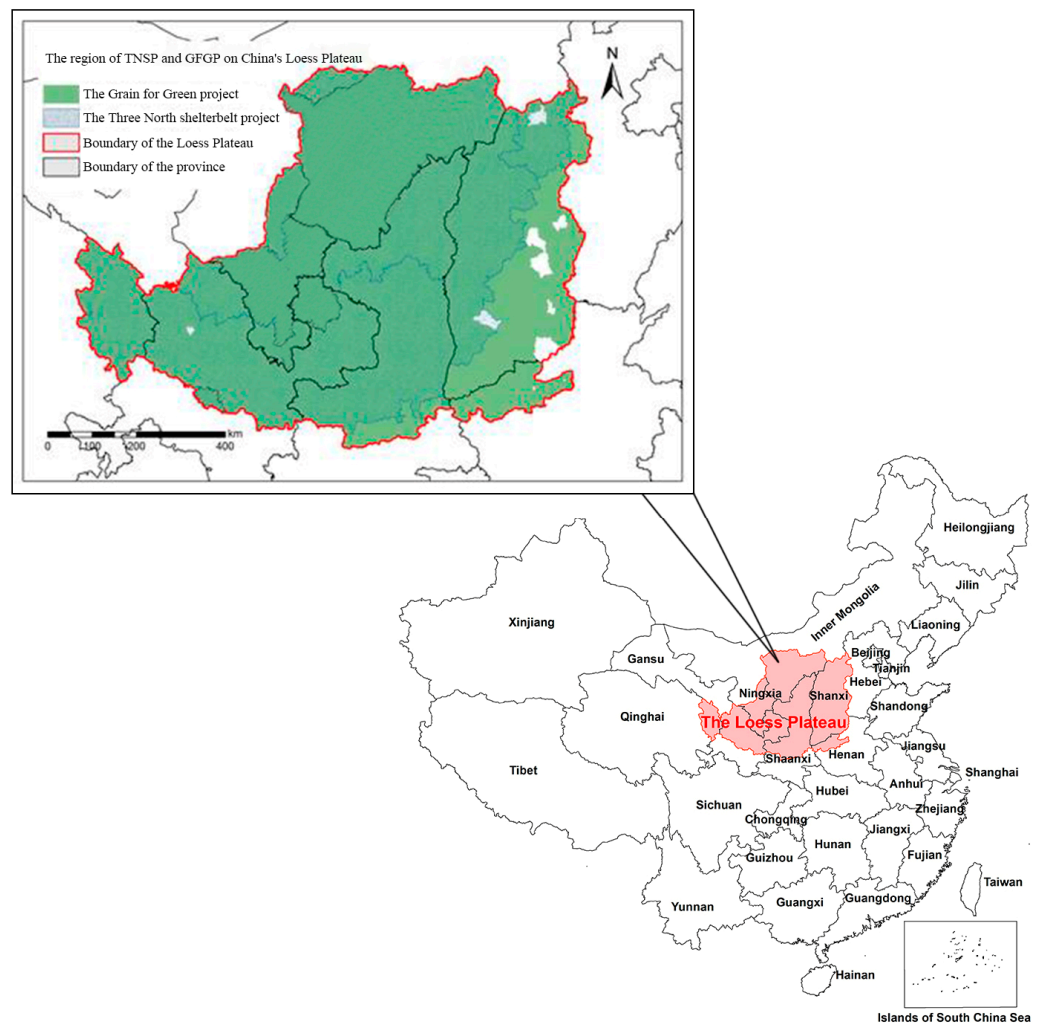

Figure 1. The location of the Loess Plateau and the covered area by the Three North Shelterbelt Project and the Grain for Green Program on the Loess Plateau.

Three dimensions, namely, biophysical consequences, socioeconomic benefits, and political goals of China's land restoration programmes, are used to address the policy shortcomings and outcomes. The selection of these three dimensions is based on the well-recognised criteria for sustainable land management (SLM) adopted by the UN (for details please see http:/ / www.fao.org/land-water/ land/sustainable-land-management/en/), which is highly relevant for combating land degradation. They underline three core issues in decision-making of land restoration: (i) maintain land resources and enhance their ecological functions, (ii) generate short-term income for land users, and (iii) ensure long-term political goals for sustainable development. Sustainable restoration and development require sustainable provision of natural resources, such as soil, water, and nutrients, for social and economic improvement. For a long period of time, land use policy and planning have followed approaches based on classical thoughts (e.g., sectoral, linear, and static views), which were subsequently adopted in the exercises of policy analyses and programme evaluations. Such views are, however, biased, as environmental resources do not exist in isolation but are interconnected and co-evolving in a complex system. Such interconnectedness (e.g., between soil and water resources, between environmental and economic development) is notably evident when resource management practices are applied. Integrating multiple core criteria and dimensions in land restoration and resource management indicates a shift from the classical thoughts to complex systematic thinking (e.g., cross-sectoral, nonlinear, and dynamic views), which emphasises the balance and optimisation of various dimensions. 
Table 1. A brief summary of the Three North Shelterbelt Program and Grain for Green Project.

\begin{tabular}{|c|c|c|c|c|c|c|}
\hline Land Policy & Timeframe & Applied Area & Goals & Measures & Anticipated Benefits & $\begin{array}{l}\text { Problems Hampering the } \\
\text { Desired Effects }\end{array}$ \\
\hline $\begin{array}{l}\text { Three North Shelterbelt } \\
\text { Program (TNSP) }\end{array}$ & $\begin{array}{l}\text { 1978-2050 } \\
\text { (present plan) }\end{array}$ & $\begin{array}{l}13 \text { provinces, } \\
\text { autonomous regions, } \\
\text { and municipalities, } \\
\text { accounting for } 42.4 \% \\
\text { of China's total } \\
\text { land area }\end{array}$ & $\begin{array}{l}\text { Control land } \\
\text { desertification; reduce } \\
\text { soil erosion and water } \\
\text { loss; improve and } \\
\text { restore land quality; } \\
\text { poverty alleviation }\end{array}$ & $\begin{array}{l}\text { Increase forest cover and } \\
\text { restore grassland on bare } \\
\text { land; use woody plantation } \\
\text { for wind break, sand fixation, } \\
\text { soil and water conservation, } \\
\text { farmland and pasture } \\
\text { protection; establish } \\
\text { plantation for bioenergy and } \\
\text { commercial forests for trade; } \\
\text { and pay compensation } \\
\text { to participants }\end{array}$ & $\begin{array}{l}\text { Controlled and improved } \\
\text { desertification; recovered } \\
\text { ecosystem functions and } \\
\text { services; and increased crop } \\
\text { production and } \\
\text { economic benefits }\end{array}$ & $\begin{array}{l}\text { Frequent droughts and poor } \\
\text { forest management lead to } \\
\text { low survival rate of } \\
\text { afforestation and low forest } \\
\text { quality, leading to } \\
\text { degradation of afforested } \\
\text { land and further land } \\
\text { desertification development; } \\
\text { insufficient compensation } \\
\text { and lack of institutional } \\
\text { supports make participants } \\
\text { suffer from deeper poverty }\end{array}$ \\
\hline $\begin{array}{l}\text { Grain For Green } \\
\text { Project (GFGP) }\end{array}$ & $\begin{array}{l}2000-2020 \\
\text { (present plan) }\end{array}$ & $\begin{array}{l}25 \text { provinces, } \\
\text { autonomous regions, } \\
\text { and municipalities, } \\
\text { accounting for } 82 \% \\
\text { of China's total } \\
\text { land area }\end{array}$ & $\begin{array}{l}\text { Improve land } \\
\text { degradation; restore } \\
\text { land-based } \\
\text { ecosystems; conserve } \\
\text { natural resources; } \\
\text { reduce soil erosion; } \\
\text { poverty alleviation }\end{array}$ & $\begin{array}{l}\text { Return steep-sloped }\left(\geq 25^{\circ}\right) \\
\text { and degraded cropland to } \\
\text { forests; increase forest and } \\
\text { grass cover on barren hills } \\
\text { and wasteland; convert } \\
\text { slopes to terraces for } \\
\text { cultivation; and pay } \\
\text { compensation to participants }\end{array}$ & $\begin{array}{l}\text { Reduced sediment load in } \\
\text { rivers; alleviated flash flood; } \\
\text { improved ecosystem health } \\
\text { and biodiversity; } \\
\text { and diversified income } \\
\text { sources and } \\
\text { improved livelihoods }\end{array}$ & $\begin{array}{l}\text { Poor soil management results } \\
\text { in unsustainable use of and } \\
\text { degradation of fertile } \\
\text { cropland; afforest using } \\
\text { non-native fast-growing } \\
\text { species dries up soil water, } \\
\text { causes high mortality rate, } \\
\text { and threatens native plants; } \\
\text { "One-size-fits-all" measures } \\
\text { cause uncertain economic } \\
\text { benefits in } \\
\text { post-compensation period }\end{array}$ \\
\hline
\end{tabular}




\section{Results}

3.1. Biophysical Consequences: Non-Integrated Land Resource Management Creates New Problems While Solving an Existing Problem

The TNSP is launched in 1978 and GFGP in 2000. TNSP is implemented in northern China to combat land desertification and recover ecological functions and services by afforestation, while GFGP is implemented to prevent soil erosion on degraded slopes and croplands by changing the land cover from crops to woody and grass plants, with additional desires to reduce poverty by diversifying income sources. One of the major results is that the forest cover in the LP region, an area the size of France, increased from 6\% in 1949 to nearly 20\% in 2009 [20,21]. While soil erosion is minimised, discharge of the Yellow River Basin significantly declined [15,22]. The average discharge of the YRB during 2000-2007 was only 30\% that of the 1950s to 1960s [23]. Soil conservation activities (e.g., afforestation, construction of sediment-trapping dams and reservoirs), with associated water extraction for irrigation, are found to be the main causes of these problems [24,25]. It will cause a water shortage of 110 billion $\mathrm{m}^{3} / \mathrm{a}$ in west China if the forest cover reaches $14.4 \%$ [5]. The disregard of potential effects of soil erosion mitigation actions on water resources resulted in unwanted water loss, thus creating a new water deficiency problem. Moreover, more intense warming and frequent drought and floods are projected for north and northwest China [26]. This makes the supply of water resources in northern China more unstable and scarce, thus exacerbating the water crisis in China.

In addition, TNSP and GFGP use non-local tree species to afforest on degraded land. Afforestation relying on few exotic fast-growing varieties removes native species and reduces biological richness. For instance, northern Shaanxi province lost, on average, 52\% of plant species at afforested sites [5]. Besides this, exotic tree species consume excessive water and create intensified water stress in semi-humid/arid regions with evidence of desiccated soil and high tree mortality rate [7], in turn threatening the survival of other native plants and accelerating genetic resource, biodiversity, and habitat losses [27]. At this point, non-integrated land resource management and overlooking the interconnections between different biophysical processes has led to ineffective management results and even created new problems while solving existing ones.

\subsection{Socioeconomic Benefits: Non-Participatory Approach and "One-Size-Fits-All" Measures Constrain Socioeconomic Development}

One of the essential goals of reversing land degradation in China is to alleviate poverty. It is commonly perceived that poverty makes people degrade land and degraded land can in turn deepen poverty [28]. It is, thus, often assumed that improved land quality and additional compensation to land users could increase land-based productivity and rural income, eventually alleviating poverty. In fact, the relationship between poverty and land degradation is far from being that simple [3]. China's programmes are generally implemented in a "top-down" mode, implying that land users are usually not consulted before the programmes start and "one-size-fits-all" measures are applied across several provinces. In GFGP, a fixed amount of monetary compensation (e.g., 22,500 RMB/ha for returning farmland to forestland in the YRB) and free seedlings are offered to programme participants, with an additional grain distribution in an amount that exceeds most households' production (e.g., annually $1575 \mathrm{~kg} /$ ha for the YRB) [29]. With the monetary and in-kind grain compensation, the composition of the rural income has changed in comparison with the prior programme period. Specifically, the proportion of the traditional cultivation-based income has significantly declined in terms of the total income, while a greater portion emerged from afforestation, livestock breeding, and other sidelines [29]. This increased farmers' total income on one hand, but also relocated the rural labours from rural to urban areas and from agriculture to non-agricultural sectors on the other hand. As a result, $90 \%$ of farmers in northern Shaanxi receive more economic benefits than the prior programme period and thus support the programme [30]. However, farmers' economic benefits in the future post-payment time are yet unknown. 
In contrast, TNSP has had more adverse effects on farmers' livelihoods. TNSP bans logging and grazing to prevent land degradation so that local farmers, forest workers, and stock-breeders lose their income sources. Insufficient compensation makes them suffer from more economic loss and become even poorer than before. For example, $35 \%$ of farmers, $47 \%$ of stock-breeders, and $60 \%$ of forest workers in northern Shaanxi experienced reduced income under TNSP [16]. Even worse, cash compensation is paid with the intention to trigger structural changes in livelihood-supporting activities of poor households. Yet, if programme participants are incapable of establishing an alternative income source during the period of compensation, they will be trapped in deeper poverty [31]. For non-voluntary participants, if the compensation is low and short-term, they will return to prior policy practices after the compensation ceases [30,32]. Therefore, the non-participatory nature, "one-size-fits-all" measures, and poor governance without proper payment, timeframe, and capacity building for self-reliance (e.g., technical support and training) have undermined the potential of well-intended socioeconomic benefits for poor land users.

\subsection{Political Goals: Implementation Outcomes Conflict with Initial Policy Targets for Sustainable Development}

Food security is a fundamental political concern for sustainable development in China as the country needs to feed $19 \%$ of the global population with less than $9 \%$ of the world's farmland [33]. To increase food security and promote sustainable development, China amended its Land Administration Law in 2004, aiming to reinforce control on land use, protect and improve the ecological environment, and ensure a sustainable use of cultivated land. In the revised law, China places a particular strict control on the protection of farmland; for example, conversion of cultivated land to other non-agricultural usages (e.g., construction) is strictly regulated. Such legal regulation is intended to protect land resources and maintain the total amount of farmland for food production. In addition to legislation, food security is also highly dependent on soil and water security. Over the past three decades, the centre of China's cereal production has shifted from the humid south to the dry north [34]. As the north becomes drier, increased food production has to rely on the overuse of local water resources. After implementing a set of programmes (particularly after implementing GFGP), the sown area on slope farmland decreased rapidly [32]. This forces the land owners enrolled in GFGP to intensify production on non-programme plots or raise more livestock to increase their income; this induces a shift from single to multi-cropping, immoderate use of chemical fertilisers and pesticides, and growing competitive leguminous fodder species (e.g., Astragalus adsurgens and Medicago sativa) [27,35]. Such activities increase farmers' welfare in the short term [35] but, with poor land management and insufficient institutional support, they lead to undesired long-term ecological consequences. For example, intensified farming lowers soil quality, depletes soil water, and accelerates farmland degradation [36], while improper practices (e.g., cultivation on untreated industrial land and irrigation using unsafe wastewater) contaminate soil and surface and underground water [37]. With an increased area of polluted land for agriculture, China's food security is threatened by a shrunken suitable sown area. These outcomes are not in line with the intention of China's Land Administration Law.

To act on the water shortage and facilitate food production in the north, China launched the South-North Water Diversion Project (SNWDP)—the world's largest inter-basin transfer scheme-to reallocate water from the wet South to the dry North for consumption and irrigation [38]. Such projects are extremely expensive and, in some cases, have induced water degradation in the source area [39]. To date, SNWTP has not shown evidence of alleviating water scarcity, but has caused water loss due to leaky canal systems and pollution from uncontrolled industrial discharge along the route during diversion and transportation, deteriorating China's water and food security $[40,41]$. These outcomes conflict with part of the initial policy targets of TNSP and GFGP, such as to maintain and improve food security and to safeguard the nation's sustainable development. 


\section{Discussion: How to Overcome These Shortcomings to Achieve Sustainable Land Restoration?}

\subsection{Formulate a Cross-Sectoral and Benefit-Sharing System in Land Use}

The root cause of such undesirable results is sectored management, namely, the implemented policies focused on one sector (e.g., forest development) or one resource (e.g., soil) and had not taken the potential impacts on other sectors or resources and possible long-term effects on farmers' livelihoods into full consideration [42]. TNSP and GFGP use increasing forest cover in water-limited areas to control soil erosion as forests can improve soil properties (e.g., pore structures and hydraulic properties) [43,44], and, thus, are beneficial for restoring soil functions; however, they also alter water moving paths (e.g., transpiration and infiltration) [45,46], resulting in interplay and competition of soil and hydrological processes. Therefore, while forests reduce soil erosion and improve water infiltration, they also decrease streamflow in rivers for downstream users due to higher upstream water use for tree growth [7]. To mitigate the conflicts and prevent further degradation of land resources, we need more sustainable land-use systems that are able to manage the competition and to balance and optimise the functions and services of different resources with minimum tradeoffs. Such types of land use are supposed to create cross-sectoral multifunctionality, thus giving its name: the multifunctional land-use (MLU) system.

Agroforestry is a well-demonstrated example of existing MLU. It harmonises water and soil conservation (ecological function) and food production (socioeconomic function) by introducing protective structures and fertiliser trees into an agricultural system [47,48]. The benefits accrued include reduced soil erosion, enhanced soil quality and biodiversity, improved crop yield and water quality, and increased carbon sequestration and incomes in marginal lands [49]. If agroforestry shows how to achieve MLU on a plot scale, how can we apply MLU at a landscape scale (e.g., watershed)? At the landscape level, spatial units are diverse in nature and potential. For example, tablelands in a watershed have fertile soil and favourable water condition, and thus have high potential for farming, while steep slopes are erosion-prone and hardly accessible, and, hence, are more feasible to cover with permanent vegetation (forest, shrubs, or grassland) for soil erosion control. This shows how a set of different spatial units can produce a spatial multifunctionality [50]. A practical way to realise such a multifunctional landscape is to identify "spatial hotspots" (either areas with high value in one service or areas with multiple services). Different prioritising and configuring methods are developed and applied to identify such hotspots, depending upon the targeted services [51]. Similarly designed land systems will be able not only to provide a range of goods and services to satisfy the local demands and social needs of neighbouring areas, but also to maintain the health and ecological functions of land resources, thus creating benefit-sharing for social and land development. Yet, all of these aspects are often not taken into full consideration in land restoration plans.

A possible way to increase the multifunctionality of afforestation to restore degraded land is by restoring native forests with a reasonable payment. Such a shift will increase biodiversity and forest product variety (e.g., honey, fruits, and herbs), in addition to desired benefits for water and soil resources. Even with an extreme assumption that no income will be generated from forest products, it will probably create an opportunity cost that is equivalent to $13 \%$ of the household annual income [52]. To make sure that sustainable measures will be adopted to prevent land degradation, relevant land users should be engaged in decision-making through participatory processes. Their engagements can be in different forms, including providing information, consultation, and co-decisions. Many past experiences confirm that a large number of innovative efforts to promote sustainable land practices have not been applied due to social unacceptance, as politicians, practitioners, and farmers often have conflicting visions and interests $[53,54]$. Moreover, the potential knowledge gaps in technology adaptability, incentive design, and feasibility of implementation can affect the social acceptance negatively. Therefore, effective communication and negotiation between experts, officials, and land users are essential to increase the chances of policy uptake. Specifically, they need to treat the land resources and economy in combination rather than in isolation. 


\subsection{Use Policy Effectiveness and Cost Efficiency as Decision-Making Tools}

For restoration strategies to be successful, they have to be policy-effective and cost-efficient, building upon ecological knowledge and socioeconomic constraints [55,56]. In general, policy effectiveness is determined by to what extent policies are working, while cost efficiency is measured by the ratio of potential benefit to investment. In contrast to cost efficiency, policy effectiveness is understudied in the scientific community. To analyse policy effectiveness, we need to set up performance criteria and to link the criteria to routinely monitored indicators. However, it is a usual case that a policy is designed without a clear definition of criteria, or with criteria that are not necessarily or comprehensively related to performance. Taking the LP China as an example, soil erosion is a severe and central land issue closely related to other resources and social problems, such as water shortage and pollution, agricultural development, and natural and public health. Policy effectiveness of afforestation activities (in the frame of TNSP and GFGP) in this area is evaluated using increased forest area and biomass volume as main indicators. Such indicators are incomprehensive, as they disregard negative ecological and socioeconomic consequences of introducing additional water losses and heightening water use competition. Therefore, policy effectiveness is a critical issue to address before analysing cost efficiency; or, in other words, cost efficiency is meaningless without an effective policy.

For policy to be effective, tradeoffs of a set of key ecosystem functions and services at different temporal and spatial scales have to be explicitly considered for minimising the overall loss of benefits. A simple but useful approach such as the "weighting diagram" (Figure 2) can be applied to depict the changes in ecosystem functions and services to alternative land restoration decisions. A group of such diagrams placed at varying time and spatial scales can assist decision makers to understand the tradeoffs and come to a reasonable decision on land use. In spite of a simple appearance, the diagrams involve a substantial load of work associated with quantification and valuations of ecological processes and consequences.

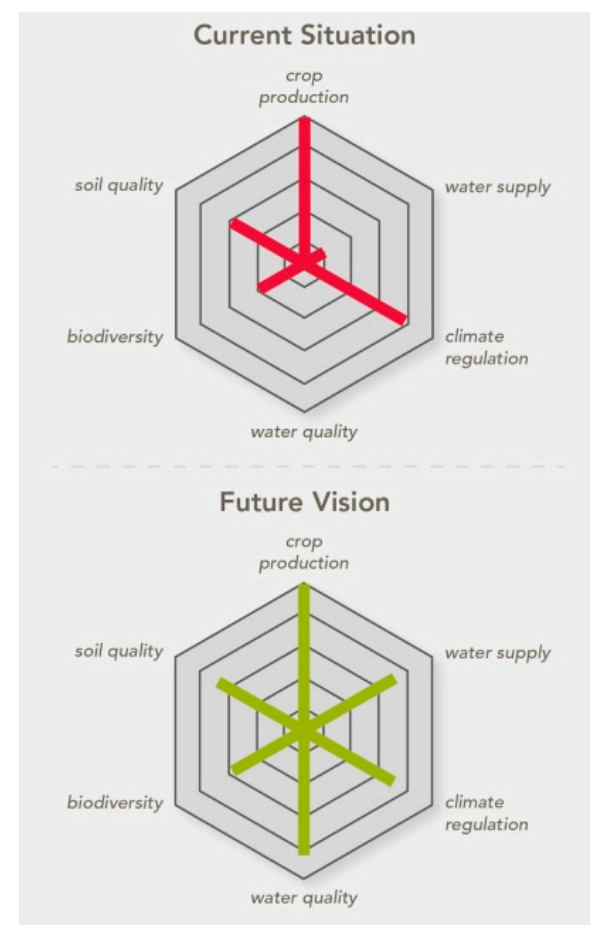

Figure 2. Tradeoffs in key ecological and social services under current and future projections for the Loess Plateau China. 
In contrast, cost efficiency is vital to lower expenditure. Restoring/protecting land resources is expensive and funds are normally limited; there is, thus, a need to maintain the desired multiple benefits with a low cost, or, in other words, optimal targeting [55,56]. In cost-benefit or optimal targeting analysis, the ratio of benefit-to-cost is commonly used as an important indicator for decision making [55]. We argue that such a solo approach may mislead investment and involve the risk of failure. Ranking of ratios will probably lead to a single solution as a result of choosing the highest ratio and consequently establishing a typical command-and-control mode. Such top-down approaches have a high possibility of social unacceptance, resulting in investments in vain. We believe there is neither an absolute nor a single solution; there are only better or worse solutions. From our perspective, certain issues (e.g., soil erosion in the loess region) can be especially critical in an area because they may not only trigger degradation of land resources, but may also be closely linked to other socioeconomic problems. In such cases, the issue can be regarded as a critical linkage to several problems; solving this one particular issue is likely to simultaneously solve or positively affect other problems. For this reason, it might be more efficient to put the costs at the critical linkages, since they are often the point of departure for increasing synergies-thus, the points for policy and financial intervention [57]. Progressive analysis, such as problem mapping, is likely to highlight the relevance of and identify the critical linkages.

\section{Conclusions}

The problems addressed in this work indicate that China's current approaches to combat land degradation have flaws, despite their successes in reducing soil erosion and increasing soil carbon. The consequences of the unsustainable management strategy of land resources suggest a shift from the old mode of 'economy versus environment' (i.e., sectored approach) to a new mode of 'economy and environment' (i.e., MLU) for a more sustainable future. Yet, solving all problems at once is impossible; a systematic approach — a series of logical and meaningful steps and analysis—is required before lining them up one-by-one. Using land restoration in the LP as an example, we suggest the following as an alternative way forward to realise the MLU:

1. Define the manifold functions of the landscape used for restoration (e.g., control soil erosion, sustain water supply, and improve crop yield and farmer livelihood)-the composition of functions probably varies over areas.

Landscape design is an essential step to meet the regional demand for land restoration, which also has to take the goals of the national programmes into consideration. The LP consists of natural and human-induced patches that are heterogeneous in nature, form, and arrangement. In some cases, the unique composition of natural elements can denote a preferable environment for a certain land use. Based on the understanding of regional demands (e.g., policymaker and land user interests) and site conditions (e.g., expert knowledge), a watershed should be divided into a set of hotspots, among which, for instance, flat tablelands are primary agricultural hotspots in view of high water and nutrient potential under adequate land degradation mitigation measures, while erosion-prone and less accessible slopes are main soil conservation hotspots covered with native trees, perennial shrubs, and grasses. Lack of spatial prioritisation of land use is still a crucial overlooked problem in the plans for restoring degraded land in China. Additionally, economic pressure also affects rural landscape dynamics. Both short-term economic benefits (e.g., livelihoods) and long-term ecological benefits (e.g., water availability and biodiversity) have to be safeguarded during the land restoration on the LP.

2. Understand the possible biophysical and socioeconomic consequences under different measures and practices in a systematic approach with a logical sequence of analysis.

Operation is difficult and challenging at small scales. To act locally, options for adaptation to meet the diverse demands of policymaker and land user have to be explored by using suitable 
tools. Biophysical interactions are complex and diverse. Model application based on improved process knowledge obtained from field observation (i.e., small scale) is an essential method as it can clarify internal process interactions and evolvements at a large scale and conduct scenario analyses that are impossible to measure. Besides this, a logical sequence of analysis is important. Taking the LP as an example, soil erosion is the central problem of land degradation that is closely linked to other resource degradation and social development problems. Analysis can use soil as a starting point to quantify the effects of a number of erosion mitigation measures on crop- and forestland. With a couple of good results, researchers can quantify the changes of individual hydrological process to those soil conservation measures in a second step. If the selected measures are effective in reducing soil erosion and favourable for water supply, chemical (e.g., water quality), biological (e.g., crop yield and biodiversity), and economic (e.g., income) analyses can be added in further steps. This highlights a full consideration of cross-sectoral impacts and a more transparent and logical order of research to understand the impacts of soil conservation measures and practices.

3. Design financing and incentive mechanisms for land restoration based on negotiation with land users-investment is only efficient when it is put in the right place.

The past implementation of TNSP and GFGP on the LP followed a typical 'command-and-follow' approach. There is highly possibly a huge gap between the officials' defined 'optimal' system and the actual 'practice' of farmers. Dialogue and negotiation, comprehensive analysis, and offering alternative options to fulfil the diverse wishes of different parties (farmers, officials, entrepreneurs, and nongovernmental organizations (NGOs)) can help to bridge this gap. In such a participatory process, a scientist becomes a 'knowledge broker' and gives a land user the right to make a decision from a number of possibilities. This can increase the chances of applying sustainable measures and practices at the end. Payment for Ecosystem Services (PES) is of particular relevance when it comes to land restoration and resource protection. It supports practices that have long-term ecological benefits beyond land users' own interests. But PES is only efficient when it is applied in the right places. Misuse of payments, such as developers paying authorities to buy the rights to damage the land, can further degrade land resources. A possible way to finance land restoration on the LP is by introducing Green Soil and Water Credit, in which upstream farmers are paid to perform soil and water conservation practices for the benefit of downstream water users. The concept of Green Credit can be convincing and relevant if the commercial interests of upstream land users are captured in cost-benefit analyses and if clear and transparent processes between experts, officials, and land users are involved to reach an agreement. Similar financing mechanisms are still absent on the LP.

We have learned lessons from China's past efforts to restore degraded land. Based on these experiences, China needs to promote a more balanced holistic approach (e.g., MLU) that can bring synergy among environment, economy, and society. The new management strategy should be effective and efficient in restoring land resources and minimising damages, as well as meeting human needs. China is not alone in facing similar challenges in managing land resources and developing the economy. Such exploration will benefit other developing countries and regions, which may adapt them to their unique environmental and socioeconomic contexts.

Acknowledgments: This work is supported by the German Research Foundation DFG funded project (SCHW 1448-3) and the core budget of the United Nations University Institute for Integrated Management of Material Fluxes and of Resources (UNU-FLORES). Special thanks go to Mathew Kurian and Yanhui Wang for their advices on improving the work and Atiqah Fairuz Salleh for copyediting of language.

Author Contributions: Lulu Zhang conceived, designed and wrote the manuscript; Kai Schwärzel contributed to developing and writing the paper.

Conflicts of Interest: The authors declare no conflict of interest. 


\section{References}

1. UNECE; OECD. Integrated Water Resources Management in Eastern Europe, the Caucasus and Central Asia. European Union Water Initiative National Policy Dialogues Progress Report 2013; United Nations: New York, NY, USA; Geneva, Switzerland, 2014.

2. Hatfield, J.L.; Sauer, T.J.; Cruse, R.M. Soil: The Forgotten Piece of the Water, Food, Energy Nexus. Adv. Agron. 2017, 143, 1-46. [CrossRef]

3. Kurian, M. The water-energy-food nexus: Trade-offs, thresholds and transdisciplinary approaches to sustainable development. Environ. Sci. Policy 2017, 68, 97-106. [CrossRef]

4. Schwärzel, K.; Ardakanian, R.; Avellán, T.; Zhang, L. Nexus Approach: Resource Management for Soil Productivity. In Encyclopedia of Soil Science, 3rd ed.; Lal, R., Ed.; CRC Press: Boca Raton, FL, USA, 2016; pp. 1530-1534, ISBN 978-1-4987-3890-3.

5. Cao, S. Impact of China's Large-Scale Ecological Restoration Program on the Environment and Society in Arid and Semiarid Areas of China: Achievements, Problems, Synthesis, and Applications. Crit. Rev. Environ. Sci. Technol. 2011, 41, 317-335. [CrossRef]

6. Cao, S.; Li, S.; Ma, H.; Sun, Y. Escaping the resource curse in China. Ambio 2015, 44, 1-6. [CrossRef] [PubMed]

7. Wang, Y.; Bonell, M.; Feger, K.-H.; Yu, P.; Xiong, W.; Xu, L. Changing forestry policy by integrating water aspects into forest/vegetation restoration in dryland areas in China. Bull. Chin. Acad. Sci. 2012, 26, 59-67.

8. MEP. 2016 Report on the State of the Environment in China. 2016. Available online: http:/ / english.sepa.gov.cn/ Resources/Reports/soe/ReportSOE/201709/P020170929573904364594.pdf (accessed on 17 December 2017).

9. United Nations. Transforming Our World: The 2030 Agenda for Sustainable Development. 2015. Available online: https:/ / sustainabledevelopment.un.org/content/documents/21252030\%20Agenda\% 20for\%20Sustainable\%20Development\%20web.pdf (accessed on 17 December 2017).

10. Wang, S.; Fu, B.; Piao, S.; Lü, Y.; Ciais, P.; Feng, X.; Wang, Y. Reduced sediment transport in the Yellow River due to anthropogenic changes. Nat. Geosci. 2016, 9, 38-41. [CrossRef]

11. Song, X.; Peng, C.; Zhou, G.; Jiang, H.; Wang, W. Chinese Grain for Green Program led to highly increased soil organic carbon levels: A meta-analysis. Sci. Rep. 2014, 4, srep04460. [CrossRef] [PubMed]

12. Zhang, J.; Zhao, T.; Jiang, C.; Cao, S. Opportunity cost of water allocation to afforestation rather than conservation of natural vegetation in China. Land Use Policy 2016, 50, 67-73. [CrossRef]

13. Zhang, J.; Ding, Z.; Luo, M. Risk analysis of water scarcity in artificial woodlands of semi-arid and arid China. Land Use Policy 2017, 63, 324-330. [CrossRef]

14. Fang, Q.; Elliott, M. China: Prevent misuse of eco-compensation. Nature 2016, 533, 321. [CrossRef] [PubMed]

15. Wang, Y.; Yu, P.; Feger, K.-H.; Wei, X.; Sun, G.; Bonell, M.; Xiong, W.; Zhang, S.; Xu, L. Annual runoff and evapotranspiration of forestlands and non-forestlands in selected basins of the Loess Plateau of China. Ecohydrology 2011, 4, 277-287. [CrossRef]

16. Cao, S.; Wang, X.; Song, Y.; Chen, L.; Feng, Q. Impacts of the Natural Forest Conservation Program on the livelihoods of residents of Northwestern China: Perceptions of residents affected by the program. Ecol. Econ. 2010, 69, 1454-1462. [CrossRef]

17. Wang, X.; Jiao, F.; Li, X.; An, S. The Loess Plateau. In Multifunctional Land-Use Systems for Managing the Nexus of Environmental Resources; Zhang, L., Schwärzel, K., Eds.; Springer International Publishing: Cham, Switzerland, 2017; pp. 11-27, ISBN 978-3-319-54957-6.

18. Ren, M. Sediment discharge of the Yellow River, China: Past, present and future-A synthesis. Acta Oceanol. Sin. 2015, 34, 1-8. [CrossRef]

19. Lü, M.-Q.; Xia, Z.-L.; Wang, J.-J. Recent changes on the Loess Plateau: Land resource development and rapid urbanization. In Restoration and Development of the Degraded Loess Plateau, China; Springer: Tokyo, Japan, 2014; pp. 255-265.

20. Chen, L.; Wei, W.; Fu, B.; Lü, Y. Soil and water conservation on the Loess Plateau in China: Review and perspective. Prog. Phys. Geogr. 2007, 31, 389-403. [CrossRef]

21. Fan, X.; Ma, Z.; Yang, Q.; Han, Y.; Mahmood, R.; Zheng, Z. Land use/land cover changes and regional climate over the Loess Plateau during 2001-2009. Part I: Observational evidence. Clim. Chang. 2014, 129, 427-440. [CrossRef] 
22. Zhang, L.; Podlasly, C.; Feger, K.-H.; Wang, Y.; Schwärzel, K. Different land management measures and climate change impacts on the runoff-A simple empirical method derived in a mesoscale catchment on the Loess Plateau. J. Arid Environ. 2015, 120, 42-50. [CrossRef]

23. Miao, C.; Ni, J.; Borthwick, A.G.L. Recent changes of water discharge and sediment load in the Yellow River basin, China. Prog. Phys. Geogr. 2010, 34, 541-561. [CrossRef]

24. Zhang, X.; Zhang, L.; Zhao, J.; Rustomji, P.; Hairsine, P. Responses of streamflow to changes in climate and land use/cover in the Loess Plateau, China. Water Resour. Res. 2008, 44, W00A07. [CrossRef]

25. Gates, J.B.; Scanlon, B.R.; Mu, X.; Zhang, L. Impacts of soil conservation on groundwater recharge in the semi-arid Loess Plateau, China. Hydrogeol. J. 2011, 19, 865. [CrossRef]

26. Piao, S.; Ciais, P.; Huang, Y.; Shen, Z.; Peng, S.; Li, J.; Zhou, L.; Liu, H.; Ma, Y.; Ding, Y.; et al. The impacts of climate change on water resources and agriculture in China. Nature 2010, 467, 43-51. [CrossRef] [PubMed]

27. Zheng, H.; Cao, S. Threats to China's Biodiversity by Contradictions Policy. Ambio 2015, 44, 23-33. [CrossRef] [PubMed]

28. Lal, R. The Nexus Approach to Managing Water, Soil and Waste under Changing Climate and Growing Demands on Natural Resources. In Governing the Nexus; Kurian, M., Ardakanian, R., Eds.; Springer International Publishing: Cham, Switzerland, 2015; pp. 39-60, ISBN 978-3-319-05746-0.

29. Zhen, L.; Hu, J. The Land Use Protective Policy in China. In Multifunctional Land-Use Systems for Managing the Nexus of Environmental Resources; Zhang, L., Schwärzel, K., Eds.; Springer International Publishing: Cham, Switzerland, 2017; pp. 29-51, ISBN 978-3-319-54956-9.

30. Cao, S.; Xu, C.; Chen, L.; Wang, X. Attitudes of farmers in China's northern Shaanxi Province towards the land-use changes required under the Grain for Green Project, and implications for the project's success. Land Use Policy 2009, 26, 1182-1194. [CrossRef]

31. Uchida, E.; Xu, J.; Xu, Z.; Rozelle, S. Are the poor benefiting from China's land conservation program? Environ. Dev. Econ. 2007, 12, 593-620. [CrossRef]

32. Liu, G.; Tsunekawa, A.; Dang, X.; Du, S. Future Development-Related Challenges on the Loess Plateau. In Restoration and Development of the Degraded Loess Plateau, China; Tsunekawa, A., Liu, G., Yamanaka, N., Du, S., Eds.; Springer: Tokyo, Japan, 2014; pp. 267-282.

33. Chen, J. Rapid urbanization in China: A real challenge to soil protection and food security. CATENA 2007, 69, 1-15. [CrossRef]

34. Yu, C. China's water crisis needs more than words. Nat. News 2011, 470, 307. [CrossRef] [PubMed]

35. Xu, Z.; Xu, J.; Deng, X.; Huang, J.; Uchida, E.; Rozelle, S. Grain for Green versus Grain: Conflict between Food Security and Conservation Set-Aside in China. World Dev. 2006, 34, 130-148. [CrossRef]

36. Liu, Y.; Pan, Z.; Zhuang, Q.; Miralles, D.G.; Teuling, A.J.; Zhang, T.; An, P.; Dong, Z.; Zhang, J.; He, D.; et al. Agriculture intensifies soil moisture decline in Northern China. Sci. Rep. 2015, 5, 11261. [CrossRef] [PubMed]

37. Le, C.; Zha, Y.; Li, Y.; Sun, D.; Lu, H.; Yin, B. Eutrophication of Lake Waters in China: Cost, Causes, and Control. Environ. Manag. 2010, 45, 662-668. [CrossRef] [PubMed]

38. State Council. The South-to-North Water Diversion Project. Engineering 2016, 2, 265-267. [CrossRef]

39. Berkoff, J. China: The South-North Water Transfer Project-Is it justified? Water Policy 2003, 5, 1-28.

40. Freeman, C. Quenching the Dragon's Thirst: The South-North Water Transfer Project-Old Plumbing for New China? CEF Cooperative Competitors Research Brief Series; Woodrow Wilson International Center for Scholars: Washington, DC, USA, 2011.

41. Barnett, J.; Rogers, S.; Webber, M.; Finlayson, B.; Wang, M. Sustainability: Transfer project cannot meet China's water needs. Nat. News 2015, 527, 295. [CrossRef] [PubMed]

42. Zhang, L.; Schwärzel, K. Implementation of multifunctional land management: Research needs. In Multifunctional Land-Use Systems for Managing the Nexus of Environmental Resources; Zhang, L., Schwärzel, K., Eds.; Springer International Publishing AG: Cham, Switzerland, 2017; p. 148, ISBN 978-3-319-54956-9.

43. Schwärzel, K.; Carrick, S.; Wahren, A.; Feger, K.-H.; Bodner, G.; Buchan, G. Soil hydraulic properties of recently tilled soil under cropping rotation compared with two-year pasture. Vadose Zone J. 2011, 10, 354-366. [CrossRef]

44. Yu, M.; Zhang, L.; Xu, X.; Feger, K.-H.; Wang, Y.; Liu, W.; Schwärzel, K. Impact of land-use changes on soil hydraulic properties of Calcaric Regosols on the Loess Plateau, NW China. J. Plant Nutr. Soil Sci. 2015, 178, 486-498. [CrossRef] 
45. Schwärzel, K.; Ebermann, S.; Schalling, N. Evidence of double-funneling effect of beech trees by visualization of flow pathways using dye tracer. J. Hydrol. 2012, 470, 184-192. [CrossRef]

46. Wahren, A.; Schwärzel, K.; Feger, K.-H. Potentials and limitations of natural flood retention by forested land in headwater catchments: Evidence from experimental and model studies. J. Flood Risk Manag. 2012, 5, 321-335. [CrossRef]

47. Korwar, G.R.; Govindarajan, V. Agroforestry Measures for Effective Soil and Water Conservation. In Techniques of Water Conservation and Rainwater Harvesting for Drought Management; Mishra, P.K., Osman, M., Satendra, Venkateswarlu, B., Eds.; Central Research Institute for Dryland Agriculture: Hyderabad, India, 2011; pp. 587-596.

48. Mbow, C.; Van Noordwijk, M.; Luedeling, E.; Neufeldt, H.; Minang, P.A.; Kowero, G. Agroforestry solutions to address food security and climate change challenges in Africa. Curr. Opin. Environ. Sustain. 2014, 6, 61-67. [CrossRef]

49. Jose, S. Agroforestry for ecosystem services and environmental benefits: An overview. Agrofor. Syst. 2009, 76, 1-10. [CrossRef]

50. Carvalho-Ribeiro, S.M.; Lovett, A.; O'Riordan, T. Multifunctional forest management in Northern Portugal: Moving from scenarios to governance for sustainable development. Land Use Policy 2010, 27, 1111-1122. [CrossRef]

51. Schröter, M.; Remme, R.P. Spatial prioritisation for conserving ecosystem services: Comparing hotspots with heuristic optimisation. Landsc. Ecol. 2016, 31, 431-450. [CrossRef] [PubMed]

52. Hua, F.; Wang, X.; Zheng, X.; Fisher, B.; Wang, L.; Zhu, J.; Tang, Y.; Yu, D.W.; Wilcove, D.S. Opportunities for biodiversity gains under the world's largest reforestation programme. Nat. Commun. 2016, 7, 12717. [CrossRef] [PubMed]

53. Bouma, J. Implications of the knowledge paradox for soil science. Adv. Agron. 2010, 106, 143-171.

54. Bouma, J.; Van Altvorst, A.C.; Eweg, R.; Smeets, P.; Van Latesteijn, H.C. The Role of Knowledge When Studying Innovation and the Associated Wicked Sustainability Problems in Agriculture. Adv. Agron. 2011, $113,283$.

55. Chen, X.; Lupi, F.; Vina, A.; He, G.; Liu, J. Using Cost-Effective Targeting to Enhance the Efficiency of Conservation Investments in Payments for Ecosystem Services. Conserv. Biol. 2010, 24, 1469-1478. [CrossRef] [PubMed]

56. Adame, M.F.; Hermoso, V.; Perhans, K.; Lovelock, C.E.; Herrera-Silveira, J.A. Selecting cost-effective areas for restoration of ecosystem services. Conserv. Biol. 2015, 29, 493-502. [CrossRef] [PubMed]

57. Alcamo, J. Systems Thinking for Advancing a Nexus Approach to Water, Soil and Waste; UNU-FLORES: Dresden, Germany, 2015; ISBN 978-3-944863-16-0. 